\title{
New organic substrates and boron fertilizing for production of yellow passion fruit seedlings
}

\section{Raissa Rachel Salustriano da Silva-Matos, Gabriel Barbosa da Silva Jr, Adenaelson de Souza Marques, Maciel Lima Monteiro, Ítalo Herbert Lucena Cavalcante \& Josy Anteveli Osajima}

To cite this article: Raissa Rachel Salustriano da Silva-Matos, Gabriel Barbosa da Silva Jr, Adenaelson de Souza Marques, Maciel Lima Monteiro, Ítalo Herbert Lucena Cavalcante \& Josy Anteveli Osajima (2016) New organic substrates and boron fertilizing for production of yellow passion fruit seedlings, Archives of Agronomy and Soil Science, 62:3, 445-455, DOI: 10.1080/03650340.2015.1050000

To link to this article: https://doi.org/10.1080/03650340.2015.1050000

Accepted author version posted online: 13

May 2015.

Published online: 02 Jun 2015.

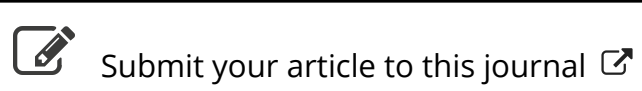

Џ Article views: 112

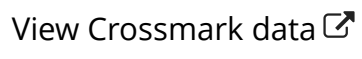

Citing articles: 2 View citing articles $[7$ 


\title{
New organic substrates and boron fertilizing for production of yellow passion fruit seedlings
}

\author{
Raissa Rachel Salustriano da Silva-Matos ${ }^{\mathrm{a}}$, Gabriel Barbosa da Silva Jr ${ }^{\mathrm{b}}$, \\ Adenaelson de Souza Marques ${ }^{\mathrm{a}}$, Maciel Lima Monteiro ${ }^{\mathrm{a}}$, \\ Ítalo Herbert Lucena Cavalcante ${ }^{\mathrm{c} *}$ and Josy Anteveli Osajima ${ }^{\mathrm{a}}$ \\ ${ }^{a}$ Department of Agronomy, Federal University of Piaui, Bom Jesus, Brazil, ${ }^{b}$ Department of Soil and \\ Fertilizers, São Paulo State University, Jaboticabal, Brazil; ' Department of Agronomy, Federal \\ University of São Francisco Valley, Petrolina, Brazil
}

(Received 19 January 2015; accepted 7 May 2015)

\begin{abstract}
The identification of alternative substrates suitable for seedling production is very important, while boron nutrition is also relevant due to plant requirement and its difficult management. Thus, four experiments were carried out from October 2012 to April 2013 to evaluate the effect of substrates using decomposed buriti (Mauritia vinifera Mart.) stem (DBS) and boron fertilizing for seedling production of yellow passion fruit (Passiflora edulis Sims). The experimental design was completely randomized in factorial scheme $6 \times 2+1$, referring to the substrates [S1: DBS, S2: soil and sand 1:1 (20\%) + DBS (80\%), S3: soil and sand 1:1 (40\%) + DBS (60\%), S4: soil and sand 1:1 (60\%) + DBS (40\%), S5: soil and sand 1:1 (80\%) + DBS (20\%), S6: commercial substrate (additional treatment) and S7: soil, sand and manure 1:1:2] with and without boron. The seedling emergence, emergence rate, plant height, stem diameter, root length, root volume and dry mass of roots and shoots were recorded. The substrates S2 (without B fertilizing) and S4 (B fertilized with $0.5 \mathrm{mg} \mathrm{dm}^{-3}$ ) produced seedlings with more than $3.0 \mathrm{~g}$ of shoot dry mass and at least $30 \mathrm{~cm}$ in height, and can be used for production of high-quality yellow passion fruit seedlings.
\end{abstract}

Keywords: Passiflora edulis Sims; seedling quality; growing media; boron

\section{Introduction}

Originally native to Brazil, its leading exporter, passion fruit (Passiflora edulis) is widely distributed throughout the tropics (FAO 2014), where it is commercially and socially important due to both soil and climatic conditions favorable for its cultivation and the possibility of consumption as fresh or processed fruit.

The seedling quality of yellow passion fruit has special importance, because it has been almost entirely grown by seeds using commercial substrates composed of expanded vermiculite and organic materials (Cavalcante et al. 2012). This substrate is expensive and does not present all the nutrients required for production of high-quality seedlings of yellow passion fruit, in need of complimentary fertilizing for most of essential nutrients, including boron, a micronutrient especially required by this fruit species (Prado et al. 2006; Sousa et al. 2011).

\footnotetext{
*Corresponding author. Email: italo.cavalcante@univasf.edu.br
} 
Therefore, several research papers have been published aiming to study the use of new organic composts as substrate for production of yellow passion fruit seedlings such as carbonized rice husks (Wagner Jr et al. 2006; Sousa et al. 2008), biochar (Cavalcante et al. 2012), coconut fiber (Oliveira et al. 2006) and alternative compounds (Almeida et al. 2011; Costa et al. 2011). Adversely, it is important to consider that a good substrate should be pathogen free, should feature high levels of soluble nutrients, and should have adequate $\mathrm{pH}$, bulk density, pore space, electrical conductivity and $\mathrm{C} / \mathrm{N}$ ratio (Abad et al. 2001; Röber \& Schacht 2008).

Among the regional materials which could be used as substrate, one could detach buriti (Mauritia vinifera Mart.), a species whose stems, after natural decomposition, have been used empirically as a substrate for the production of vegetables and seedling formation of native species (Cavalcante et al. 2011).

Another important factor for high-quality seedlings is an appropriate nutritional status, mainly for boron (Röber \& Schacht 2008), whose functions in the plant have been associated with water relations, sugar translocation, cation and anion absorption, pollen viability and the metabolism of N, P, carbohydrates and fats. Although boron is essential for crop growth, the amount required depends on plant species, and the range of proper application is rather narrow and a harmful effect can be induced by its excessive application, which renders it difficult to manage (Marschner 2005). Accordingly, yellow passion fruit plant has a high boron demand (Prado et al. 2006), so the use of a substrate able to supply the seedlings on this important nutrient is a breakthrough on the seedling production system of yellow passion fruit.

Hence, the present study aimed to evaluate the effect of different substrates using decomposed buriti stem (DBS) and boron fertilizing on seedling production of yellow passion fruit.

\section{Material and methods}

\section{Plant materials and growth conditions}

Yellow passion fruit (Passiflora edulis Sims f. flavicarpa Deg.) seedlings cv. Yellow Giant propagated by seeds (Top Seed ${ }^{\circledR}$, Brazil) were used in the experiments.

All four experiments were carried out from October 2012 to April 2013 in a net house (50\% luminosity) at the Federal University of Piaui, Bom Jesus County, Brazil, under a Caw climate with an average precipitation of $1400 \mathrm{~mm}$ per year.

During the execution of the four experiments, the climatic data were collected inside the net house, using a digital thermo hygrometer (Instrutemp ${ }^{\circledR}$, Brazil) for temperature and relative humidity measurements and a digital light meter (Instrutemp ${ }^{\circledR}$, Brazil) for luminosity, while outside the rainfall was recorded. The climate variables data monitored are shown in Figure 1.

\section{Treatments and experimental design}

The experimental design was randomized blocks with treatments distributed in a factorial arrangement $6 \times 2+1$, referring to substrate compositions [S1: decomposed buriti stem (Mauritia vinifera Mart.) (DBS) (100\%), S2: soil and sand 1:1 (20\%) + DBS (80\%), S3: soil and sand 1:1 (40\%) + DBS (60\%), S4: soil and sand 1:1 (60\%) + DBS (40\%), S5: soil and sand 1:1 (80\%) + DBS (20\%), S6: commercial substrate (CS, Plantmax ${ }^{\circledR}$, Brazil) (additional treatment without boron) and S7: soil, sand and manure 1:1:2], with and 

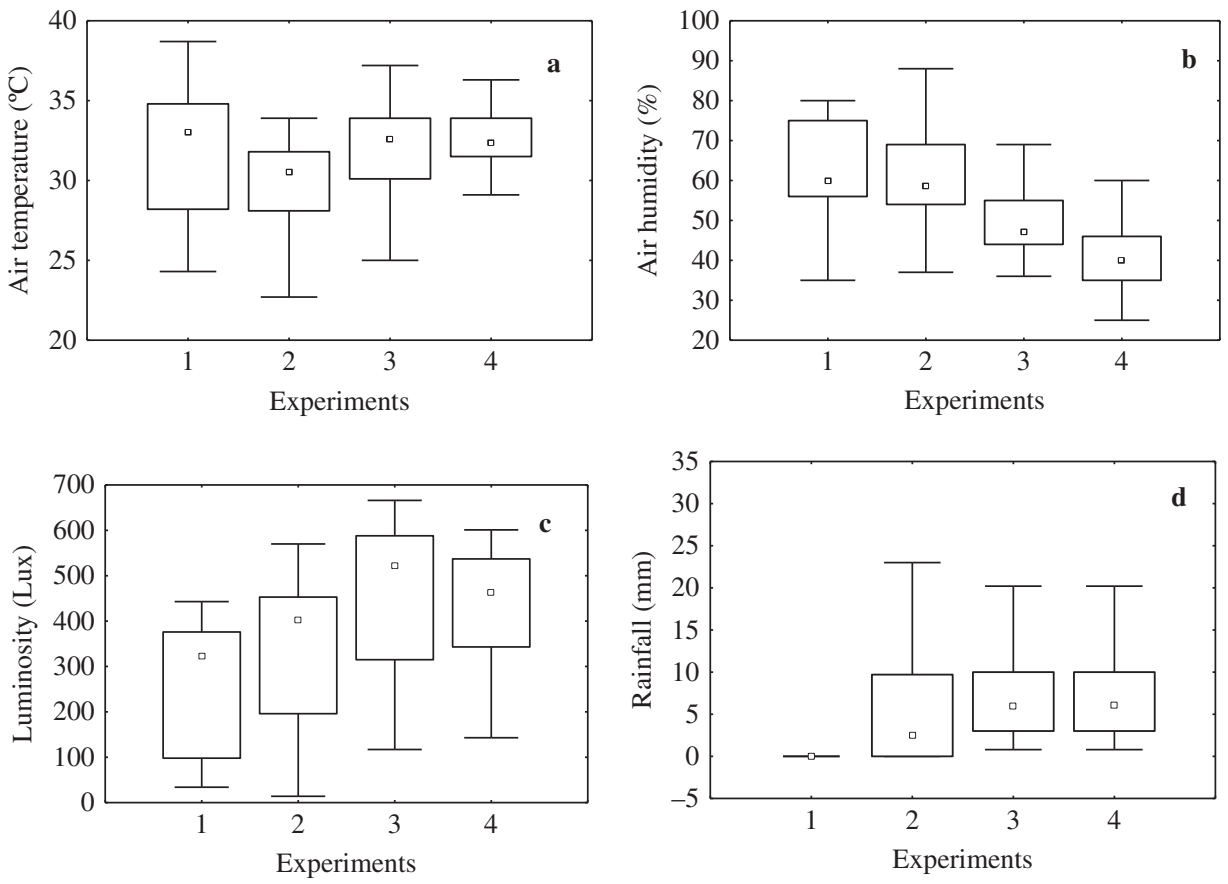

Figure 1. Dispersion diagrams of air temperature (a), air humidity (b), luminosity (c) and rainfall (d) according to the experiments. в: median; प: 25-75\%; 工: non-outlier range.

without boron in the substrate. In treatments with boron fertilizing, the nutrient was provided at a dose of $0.5 \mathrm{mg} \mathrm{dm}^{-3}$ of B using boric acid $\left(17 \mathrm{~g} \mathrm{~kg}^{-1}\right.$ of B) as a source, following Prado et al. (2006) recommendations. Four replicates with 10 plants per plot were used.

Plants were grown in $2.5 \mathrm{~L}$ capacity polyethylene pots $(16 \mathrm{~cm}$ in height and $6.4 \mathrm{~cm}$ in base diameter) and manually irrigated on a daily basis according to plant requirements in an attempt to keep the substrates as close as possible to field condition. The field capacity of the pots was determined by saturating the substrate with water. The pots were covered with plastic sheets and left to drain. Pot weights were recorded after complete drainage. The weight of soil moisture at field capacity was calculated as the difference between the soil weight after drainage and soil weight after oven drying for $105^{\circ} \mathrm{C}$ for $24 \mathrm{~h}$. Once a day, all pots were weighed (digital scale Balmak Economic ${ }^{\circledR}$ ) and irrigation water was added to the substrates to achieve a moisture content of $70 \%$ of field capacity. The characteristics of the materials used for substrates used are shown in Table 1.

Each substrate was fertilized with $450 \mathrm{mg} \mathrm{dm}^{-3}$ of $\mathrm{P}_{2} \mathrm{O}_{5}$ (Machado 1998), $300 \mathrm{mg}$ $\mathrm{dm}^{-3}$ of $\mathrm{N}, 150 \mathrm{mg} \mathrm{dm}^{-3}$ of $\mathrm{K}_{2} \mathrm{O}$ and $5 \mathrm{mg} \mathrm{dm}^{-3}$ of $\mathrm{Zn}$ (Malavolta et al. 1997). Nitrogen and $\mathrm{K}$ were divided into three parcels at 15, 30 and 45 days after sowing; $\mathrm{P}$ and $\mathrm{Zn}$ were added at sowing, together with treatments with $\mathrm{B}$. Three seeds were sown per pot and after seedling emergence (SE) plants were thinned to one per pot. The DBS was obtained from swamps of Bom Jesus County, naturally decomposed. 
Table 1. Physical and chemical characteristics of bovine manure, decomposed buriti stems (DBSs), soil and commercial substrate (CS) used in the experiments.

\begin{tabular}{|c|c|c|c|c|}
\hline Variable & Bovine manure & DBS & Soil & $\mathrm{CS}$ \\
\hline Organic matter $\left(\mathrm{g} \mathrm{kg}^{-1}\right)$ & 0.156 & 0.594 & 0.002 & - \\
\hline $\mathrm{pH}\left(\mathrm{H}_{2} \mathrm{O}\right)$ & 9.09 & 7.04 & 5.33 & - \\
\hline \multirow[t]{2}{*}{$\mathrm{N}\left(\mathrm{g} \mathrm{kg}^{-1}\right)$} & - & 21.18 & - & - \\
\hline & \multicolumn{4}{|c|}{$\mathrm{cmol}_{\mathrm{c}} \mathrm{dm}^{-3}$} \\
\hline Calcium $\left(\mathrm{Ca}^{2+}\right)$ & 4.40 & 8.80 & 0.32 & - \\
\hline Magnesium $\left(\mathrm{Mg}^{2+}\right)$ & 1.50 & 7.90 & 0.24 & - \\
\hline$\left(\mathrm{Ca}^{2+}+\mathrm{Mg}^{2+}\right)$ & 5.90 & 16.90 & 0.56 & - \\
\hline $\mathrm{K}^{+}$ & - & - & 0.01 & - \\
\hline Aluminum $\left(\mathrm{Al}^{3+}\right)$ & 0.00 & 0.00 & 0.36 & - \\
\hline Sodium $\left(\mathrm{Na}^{+}\right)$ & 19.58 & 0.95 & 0.01 & - \\
\hline \multirow[t]{2}{*}{$\mathrm{H}^{+}+\mathrm{Al}^{3+}$} & 2.97 & 1.82 & 1.10 & - \\
\hline & \multicolumn{4}{|c|}{$\mathrm{mg} \mathrm{dm}{ }^{-3}$} \\
\hline Phosphorus & 2785.00 & 168.00 & 11.08 & - \\
\hline Potassium $\left(\mathrm{K}^{+}\right)$ & $12,109.00$ & 404.00 & 30.00 & - \\
\hline Boron (B) & 2.10 & 2.03 & 0.42 & - \\
\hline $\mathrm{pH}^{*}$ & - & - & - & $6.00( \pm 0.5)$ \\
\hline WRC & - & - & - & $550 \%$ \\
\hline $\mathrm{EC}^{*}$ & - & - & - & $1.1( \pm 0.3) \mathrm{MS} \mathrm{cm}^{-1}$ \\
\hline Density & - & - & - & $85 \mathrm{~kg} \mathrm{~m}^{-3}$ \\
\hline Maximum humidity & - & - & - & $55 \%$ \\
\hline
\end{tabular}

Note: $\mathrm{P}, \mathrm{K}, \mathrm{Na}$ : Melich extractor; $\mathrm{H}+\mathrm{Al}$ : extractor calcium acetate $0.5 \mathrm{M}, \mathrm{pH} 7$; $\mathrm{Al}, \mathrm{Ca}, \mathrm{Mg}$ : extractor $\mathrm{KCl}$ $1.0 \mathrm{M}$; * analysis method 1:5; WRC: water retention capacity; EC: electrical conductivity.

\section{Variables recorded and statistical analyses}

At the end of each trial the following variables were recorded: (1) SE (\%): when seedlings appeared visibly from the soil surface they were considered as emerged, and counted. After sowing, SE was monitored daily during peak and at 2-day intervals during nonpeak periods; (2) emergence rate (ER): calculated by a speed emergence method proposed by Maguire (1962); (3) plant height $(\mathrm{PH})(\mathrm{cm})$ : measured from the base of the plant to the insertion of the youngest leave; (4) stem diameter $(\mathrm{mm})$ : obtained with a digital paquimeter (0.01-300 mm, Digimess $\left.{ }^{\circledR}\right)$.

After shoot evaluation, all plants were removed from the substrate and floated in a beaker containing deionized water. Shoots were separated from roots and root systems, washed and the root variables were recorded: (1) root length $(\mathrm{cm})$ : determined using a millimeter ruler; (2) root volume $\left(\mathrm{cm}^{3}\right)$ : recorded by measuring the water column displacement in a graduated beaker promoted by roots, having a known volume of water $(100 \mathrm{~mL})$. The difference of volume was characterized as the root volume through the unity equivalency $\left(1 \mathrm{~mL}=1 \mathrm{~cm}^{3}\right)$, according to the methodology of Basso (1999); (3) dry mass of roots and shoots $(\mathrm{g})$ : plant parts were dried at $70^{\circ} \mathrm{C}$ for 48 hours, and the mass of each plant part was determined in a Sartorious ${ }^{\circledR}$ brand precision balance $(0.01 \mathrm{~g}$ precision $)$ and expressed as $g$ plant ${ }^{-1}$.

Statistical analyses included analysis of variance (ANOVA), mean separation on substrates and B fertilizing data using Tukey's test, using combined data of the four 
consecutive trials. All the calculations were performed using the SigmaPlot software and the terms were considered significant at $p<0.01$.

\section{Results and discussion}

All variables recorded in the present study depended on substrate, while only ER was not affected by boron fertilizing (Tables 1 and 2).

In the present study, significant interactions between substrate composition and boron fertilizing were registered for all variables studied, except for ER (Table 2).

As can be seen in Table 2, ER depended on substrate used for seedling production with higher average recorded for S1 (100\% of DBS), i.e., seedlings emerged in less time, or faster, than in other substrates. The ER mean value recorded for S1 is higher than those registered by Lopes et al. (2007) in a study about yellow passion fruit as a function of substrates. The beginning of emergence was considered to be at 8 days after sowing, $50 \%$ less time than that required by the commercial substrate Plantmax ${ }^{\circledR}$ (Wagner et al. 2006), which could be caused by the high temperatures recorded during the execution of the experiments (Figure 1).

SE was significantly affected by substrates and boron fertilizing (Figure 2). For substrate S1, the boron fertilizing promoted nearly 50\% less SE than those without this nutrient, which could be caused by a toxic effect of boron, as was also reported by Mirshekari (2012), who observed that higher B concentrations in the priming solutions affected seed germination negatively, while lower concentrations are benefic.

Table 2. Emergence rate (ER), seedling emergence (SE), plant height (PH) and stem diameter (SD) of yellow passion fruit seedlings as a function of substrate and boron fertilizing.

\begin{tabular}{|c|c|c|c|c|}
\hline & & SE & $\mathrm{PH}$ & SD \\
\hline & ER & $\%$ & $\mathrm{~cm}$ & $\mathrm{~mm}$ \\
\hline $\mathrm{S}$ (substrates) ' $\mathrm{F}$ ' value & $5.08 * *$ & $4.66^{* *}$ & $8.43 * *$ & $17.87 * *$ \\
\hline S1 & $3.31 \mathrm{a}$ & $51.50 \mathrm{ab}$ & $18.41 \mathrm{bc}$ & $2.69 \mathrm{cde}$ \\
\hline $\mathrm{S} 2$ & $3.22 \mathrm{ab}$ & $61.12 \mathrm{a}$ & $20.49 \mathrm{bc}$ & $3.13 \mathrm{bcd}$ \\
\hline S3 & $3.24 \mathrm{ab}$ & $46.29 \mathrm{~b}$ & $24.29 \mathrm{ab}$ & $3.15 \mathrm{bc}$ \\
\hline S4 & $3.15 \mathrm{ab}$ & $39.25 b$ & $31.86 \mathrm{a}$ & $3.77 \mathrm{a}$ \\
\hline S5 & $2.89 \mathrm{abc}$ & $52.54 \mathrm{ab}$ & $24.76 \mathrm{ab}$ & $3.37 \mathrm{ab}$ \\
\hline S6 & $2.33 \mathrm{bc}$ & $49.13 \mathrm{ab}$ & $15.41 \mathrm{c}$ & $2.55 \mathrm{e}$ \\
\hline S7 & $2.07 \mathrm{c}$ & $47.33 \mathrm{~b}$ & $18.59 \mathrm{bc}$ & $2.68 \mathrm{de}$ \\
\hline LSD & 0.96 & 13.62 & 8.30 & 0.46 \\
\hline B (Boron fertilizing) ' $F$ ' value & $0.26^{\mathrm{ns}}$ & $72.52 * *$ & $22.13^{* *}$ & $43.54 * *$ \\
\hline B0 & $2.84 \mathrm{a}$ & $59.57 \mathrm{a}$ & $25.33 \mathrm{a}$ & $3.31 \mathrm{a}$ \\
\hline B1 & $2.93 \mathrm{a}$ & $39.62 b$ & $18.62 \mathrm{~b}$ & $2.79 \mathrm{~b}$ \\
\hline LSD & 0.33 & 4.74 & 2.89 & 0.16 \\
\hline $\mathrm{S} \times \mathrm{B} ' \mathrm{~F}^{\prime}$ value & $0.62^{\mathrm{ns}}$ & $13.42 * *$ & $6.60 * *$ & $8.51 * *$ \\
\hline CV (\%) & 21.41 & 17.68 & 24.31 & 9.62 \\
\hline
\end{tabular}

Notes: LSD, least significant difference; CV, coefficient of variation; S1, DBS (100\%); S2, soil and sand 1:1 $(20 \%)+$ DBS $(80 \%) ;$ S3, soil and sand $1: 1(40 \%)+$ DBS $(60 \%) ;$ S4, soil and sand $1: 1(60 \%)+$ DBS $(40 \%) ;$ S5, soil and sand 1:1 (80\%) + DBS (20\%); S6, commercial substrate; S7, soil, sand and manure, 1:1:2; B0, no boron; $\mathrm{B} 1$, with boron in the substrate; ns, not significant; ** significant at $p<0.01$ probability error. The means followed by the same letter in each column are not statistically different by Tukey's test. 


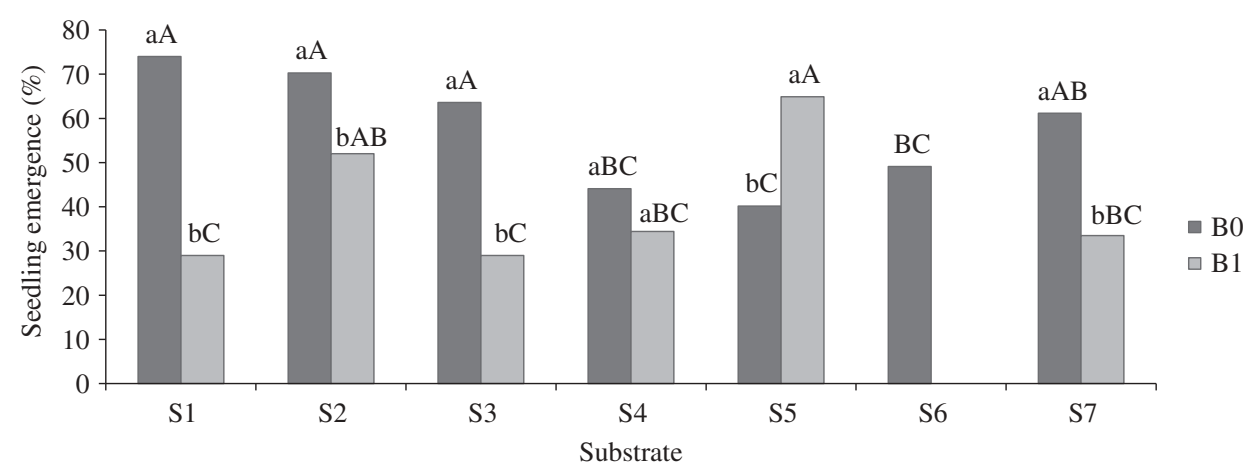

Figure 2. Seedling emergence of yellow passion fruit as a function of different substrates and boron fertilizing.

Notes: Bars with the same capital letters do not differ in substrate composition among themselves by Tukey's test at $p<0.01$ probability error. Bars with the same lowercase letters do not differ as to whether or not boron fertilizing, by Tukey test at $p<0.01$ probability error. S1, DBS $(100 \%)$; S2, soil and sand 1:1 (20\%) + DBS (80\%); S3, soil and sand 1:1 (40\%) + DBS (60\%); S4, soil and sand 1:1 (60\%) + DBS (40\%); S5, soil and sand 1: $1(80 \%)+$ DBS (20\%); S6, commercial substrate; $\mathrm{S} 7$, soil, sand and manure, 1:1:2; B0, no boron fertilizing; B1, substrate boron fertilized.

In a general form, higher SE was registered in substrates composed of DBS due to its chemical and physical characteristics (Figure 2), because according to Hörn (1996) environmental conditions directly surrounding a seed (water retention capacity, light, $\mathrm{pH}$ and soil density) determine the germination success and subsequent SE and establishment.

The highest PH was registered for substrates S3, S4 and S5 (similar among them), while S6 (commercial substrate) promoted the lowest average (Figure 3(a)). Boron affected positively the PH for S4 and S5 (Figure 3(a)), which could be caused by the lowest DBS proportion of these substrates and, consequently, lower B provided, because B participates in complexes such as mannitol, polimanuronic acid and other constituents of cell walls, directly involved in cell elongation and division (Marschner 2005). The B importance for PH was studied by Oyinlola (2007), who observed that PH increased as a function of B fertilizing, but declined after a toxic limit.

When comparing the $\mathrm{PH}$ of the present study with those recorded in the scientific literature, it is possible to infer that $\mathrm{PH}$ from seedlings grown in substrates S1, S2 [soil and sand 1:1 (20\%) + DBS (80\%)] and S3 [soil and sand 1:1 (40\%) + DBS (60\%)] (without boron) and S4 [soil and sand 1:1 (60\%) + DBS (40\%)] and S5 [soil and sand 1: 1 $(80 \%)+$ DBS $(20 \%)]$ (boron fertilized) is higher than results reported by either Costa et al. (2011) or Cavalcante et al. (2013) and close to average values recorded by Cavalcante et al. (2012).

As also observed for $\mathrm{PH}$, the stem diameter and shoot dry weight were statistically higher in substrates with greater proportions of DBS and no added boron, while the opposite occurred in substrates with smaller proportions of DBS (S4 and S5) (Figure 3(c)). This result indicates that the boron concentration of DBS was probably enough to supply the B plant requirement, based on the maximum soil concentration of $0.5 \mathrm{mg} \mathrm{dm}^{-3}$ of B defined by Prado et al. (2006). The stem diameter averages from seedlings grown in substrates S1, S2 and S3 (without boron) and S4 and S5 (boron 

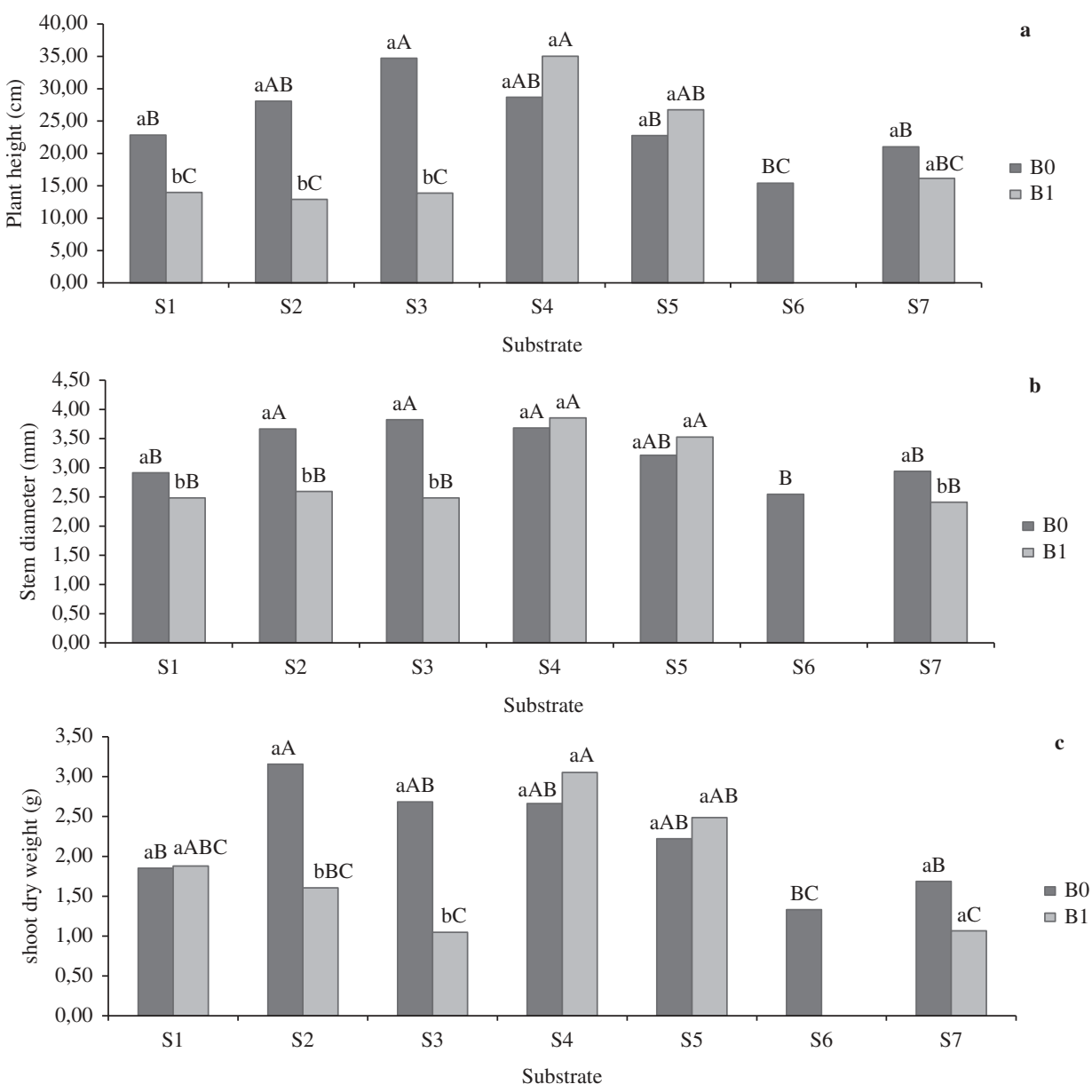

Figure 3. Plant height (a), stem diameter (b) and shoot dry weight (c) of yellow passion fruit seedlings as a function of substrate and boron fertilizing.

Notes: Bars with the same capital letters do not differ in substrate composition among themselves by Tukey's test at $p<0.01$ probability error. Bars with the same lowercase letters do not differ as to whether or not boron fertilizing, by Tukey test at $p<0.01$ probability error. S1, DBS (100\%); S2, soil and sand 1:1 (20\%) + DBS (80\%); S3, soil and sand 1:1 (40\%) + DBS $(60 \%)$; S4, soil and sand 1:1 (60\%) + DBS (40\%); S5, soil and sand 1: $1(80 \%)+$ DBS (20\%); S6, commercial substrate; $\mathrm{S} 7$, soil, sand and manure, 1:1:2; B0, no boron fertilizing; B1, substrate boron fertilized.

fertilized) are close to results quoted in the scientific literature such as Cavalcante et al. (2013) and higher than $1.8 \mathrm{~mm}$ maximum value reported by Cavalcante et al. (2012).

Shoot dry mass for S1 was not affected by boron fertilizing (Figure 3(c)), a different result from $\mathrm{PH}$ and stem diameter, showing that plant organs are differently affected by boron fertilizing. This result was previously expected since B nutrition in vascular plants, such as yellow passion fruit, has been related with cell wall synthesis and structure, membrane integrity and function, changes in the accumulation of phenolics and polyamines (Martín-Rejano et al. 2011), although the primary physiological effect of B in plant nutrition is an elusive topic. 
Table 3. Root volume (RV), root length (RL), shoots dry mass (SDM) and root dry mass (RDM) of yellow passion fruit seedlings as a function of substrate and boron fertilizing.

\begin{tabular}{|c|c|c|c|c|}
\hline & RV & RL & SDM & $\mathrm{RDM}$ \\
\hline & $\mathrm{cm}^{3}$ & $\mathrm{~cm}$ & \multicolumn{2}{|c|}{$\mathrm{g}$} \\
\hline $\mathrm{S}$ (Substrates) ' $\mathrm{F}$ ' value & $13.01 * *$ & $10.73^{* *}$ & $8.46^{* *}$ & $13.61 * *$ \\
\hline $\mathrm{S} 1$ & $6.77 \mathrm{bc}$ & $25.30 \mathrm{ab}$ & $1.87 \mathrm{bc}$ & $0.55 \mathrm{bc}$ \\
\hline S2 & $7.58 \mathrm{~b}$ & $25.17 \mathrm{ab}$ & $2.38 \mathrm{ab}$ & $0.69 \mathrm{ab}$ \\
\hline S3 & $8.34 \mathrm{ab}$ & $27.22 \mathrm{a}$ & $1.87 \mathrm{bc}$ & $0.61 \mathrm{~b}$ \\
\hline $\mathrm{S} 4$ & $10.19 \mathrm{a}$ & $26.17 \mathrm{ab}$ & $2.86 \mathrm{a}$ & $0.90 \mathrm{a}$ \\
\hline S5 & $8.89 \mathrm{ab}$ & $21.53 \mathrm{bc}$ & $2.35 \mathrm{ab}$ & $0.71 \mathrm{ab}$ \\
\hline S6 & $5.02 \mathrm{c}$ & $17.87 \mathrm{c}$ & $1.33 \mathrm{c}$ & $0.38 \mathrm{c}$ \\
\hline S7 & $4.82 \mathrm{c}$ & $19.19 \mathrm{c}$ & $1.38 \mathrm{c}$ & $0.39 \mathrm{c}$ \\
\hline LSD & 2.42 & 4.91 & 0.85 & 0.22 \\
\hline B (Boron fertilizing) ' $F$ ' value & $20.39 * *$ & $38.74 * *$ & $17.19^{* *}$ & $27.95^{* *}$ \\
\hline B0 & $8.31 \mathrm{a}$ & $25.84 \mathrm{a}$ & $2.31 \mathrm{a}$ & $0.71 \mathrm{a}$ \\
\hline B1 & $6.43 \mathrm{~b}$ & $20.58 \mathrm{~b}$ & $1.70 \mathrm{~b}$ & $0.51 \mathrm{~b}$ \\
\hline LSD & 0.84 & 1.71 & 0.29 & 0.08 \\
\hline $\mathrm{S} \times \mathrm{B}^{\prime} \mathrm{F}^{\prime}$ value & $5.20^{* *}$ & $7.35^{* *}$ & $4.89 * *$ & $7.69 * *$ \\
\hline CV $(\%)$ & 21.13 & 13.63 & 27.14 & 23.30 \\
\hline
\end{tabular}

Notes: LSD: least significant difference; CV, coefficient of variation; S1, decomposed buriti stem (100\%); S2, soil and sand 1:1 (20\%) + DBS (80\%); S3, soil and sand 1:1 (40\%) + DBS (60\%); S4, soil and sand 1:1 $(60 \%)+$ DBS $(40 \%)$; S5, soil and sand 1:1 (80\%) + DBS (20\%); S6, commercial substrate; S7, soil, sand and manure, 1:1:2; B0, no boron; B1, with boron in the substrate; ** significant at $p<0.01$ probability error. The means followed by the same letter in each column are not statistically different by Tukey's test.

All root variables depended on substrate and boron fertilizing, while all interactions between these factors were significant (Table 3).

Root volume, root length and root dry mass presented the same data distribution as a function of substrate and boron fertilizing, i.e., the highest averages were registered for substrates S3, S4 and S5 (similar among them), while S6 (commercial) promoted the lowest average (Table 3). Boron affected positively the root system for S4 and S5 (Figure 4), which could be caused by the lowest DBS proportion, while for the other substrates the boron fertilizing was deleterious, perhaps causing a toxic effect. This way, Wang et al. (2010) argue that B toxicity rapidly induced inhibition of root elongation because it has been shown that root apex is the critical site for sensing and expressing B toxicity, which possibly happened in the present experiment for S4 and S5 substrates.

As can be seen in Figure 4, there was a similar result between root volume and root dry mass, showing that the effect of the substrates studied and the boron fertilizing were different in relation to root length. This result is in line with Martín-Rejano et al. (2011) who studied the root system architecture of Arabidopsis seedlings cultivated in low boron soil and concluded that low B treatment causes a decrease in primary root elongation without affecting the growth of lateral root. Although it is well documented that B deficiency causes a rapid decrease in root growth, which has been explained as a consequence of the structural role of B in the cell wall, the same authors argue that B excess exerts a deleterious effect on root development. 

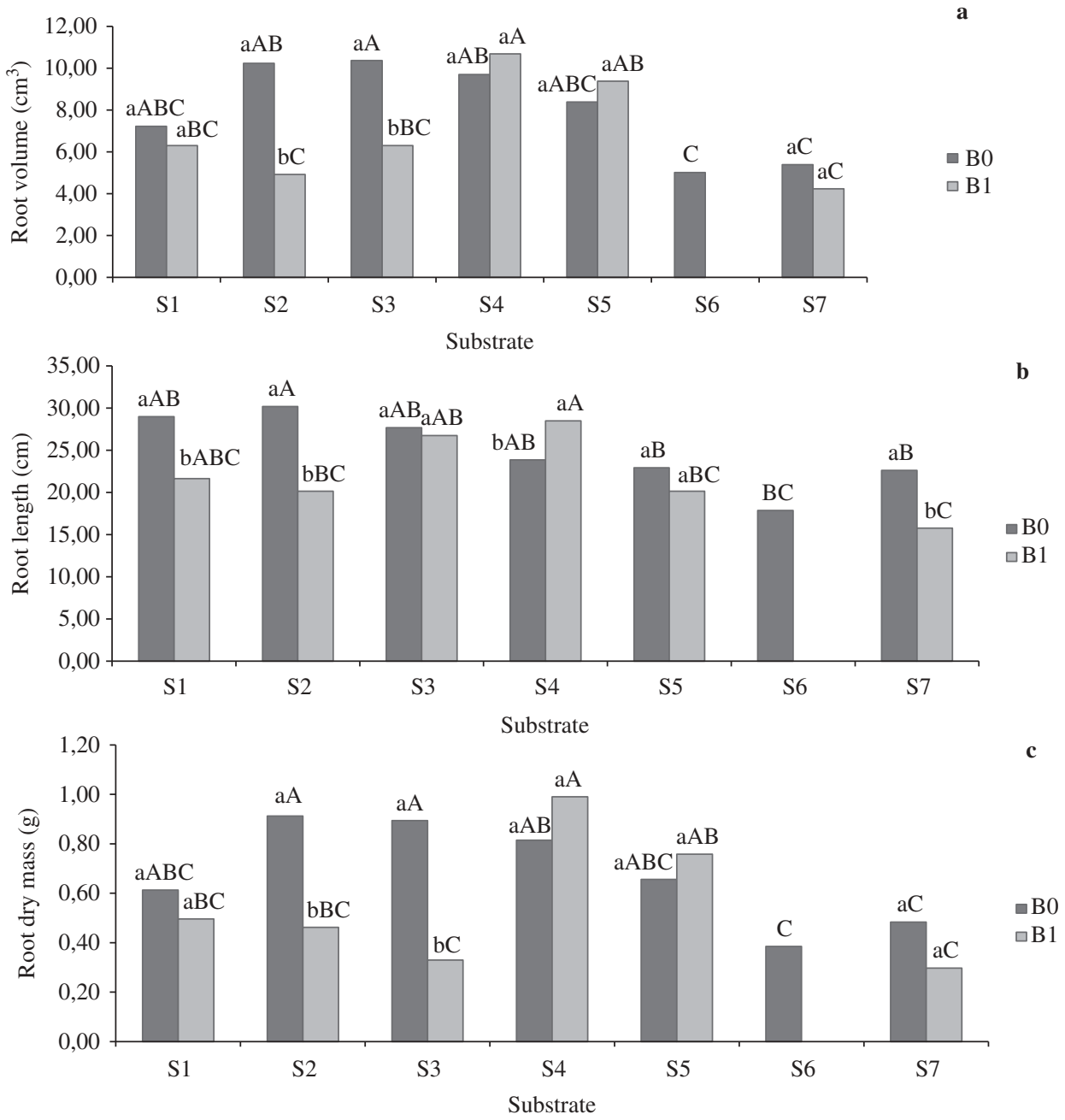

Figure 4. Root volume (a), root length (b) and root dry mass (c) of yellow passion fruit seedlings as a function of substrate and boron fertilizing.

Notes: Bars with the same capital letters do not differ in substrate composition among themselves by Tukey's test at $p<0.01$ probability error. Bars with the same lowercase letters do not differ as to whether or not boron fertilizing, by Tukey test at $p<0.01$ probability error. S1, DBS (100\%); S2, soil and sand 1:1 (20\%) + DBS (80\%); S3, soil and sand 1:1 (40\%) + DBS $(60 \%)$; S4, soil and sand $1: 1(60 \%)+$ DBS (40\%); S5, soil and sand 1:1 (80\%) + DBS (20\%); S6, commercial substrate; S7, soil, sand and manure, 1:1:2; B0, no boron fertilizing; B1, substrate boron fertilized.

Root length averages recorded in plants grown in substrates S1, S2 and S3 (without boron) and S4 and S5 (boron fertilized) are compatible to results registered by Cavalcante et al. (2013), and much higher than values referred by Cavalcante et al. (2012).

In relation to root system, it is important to detach that root growth and development are regulated by a complex interaction of hormone signaling pathways, especially auxin which has a central role as it is fundamental in initiating and organizing this process 
(Galinha et al. 2009) and the interaction between plant hormones and boron acts directly on the growth and development of plants.

\section{Conclusions}

Thus, our studies demonstrate that (1) the seedling quality of yellow passion fruit is directly affected by the substrates using DBSs and boron fertilizing; (2) the substrates composed by soil and sand 1:1 (20\%) + DBS (80\%) (without B fertilizing) and soil and sand 1:1 (60\%) + DBS (40\%) (with B fertilizing) provide high-quality yellow passion fruit seedlings; and (3) DBSs can be used in the composition of the substrate for the formation of yellow passion fruit seedlings, as a substitute to boron fertilization.

\section{Disclosure statement}

No potential conflict of interest was reported by the authors.

\section{Funding}

This work was supported by the CNPq (National Council for Scientific and Technological Development) [grant number 133781/2010-0]; and the FAPEPI (Foundation for Research Support of Piaui State) [grant number 20203.0816/2008].

\section{References}

Abad M, Noguera P, Burés S. 2001. National inventory of organic wastes for use as growing media for ornamental potted plant production: case study in Spain. Biores Technol. 77:197-200.

Almeida JPN, Barros GL, Silva GBP, Procópio IJS, Mendonça V. 2011. Substratos alternativos na produção de mudas de maracujazeiro amarelo em bandeja [Alternative substrates for production of passion fruit seedlings round in tray]. Rev Verde. 6:188-195.

Basso SMS. 1999. Caracterização morfológica e fixação biológica de nitrogênio de espécies de Adesmia DC. E Lotus L. [Morphological characterization and nitrogen biological fixation of Adesmia DC. and Lotus L.] [Ph.D. thesis]. Porto Alegre (RS): Federal University of Rio Grande do Sul.

Cavalcante IHL, da Silva-Matos RRS, Albano FG, da Silva Jr GB, Ams S, Costa LS. 2013. Foliar spray of humic substances on seedling production of yellow passion fruit. J Food Agric Environ. 11:301-304.

Cavalcante IHL, Petter FA, Albano FG, Silva RRS, Silva Jr GB. 2012. Biochar no substrato para produção de mudas de maracujazeiro amarelo [Biochar on substrate for seedling production of yellow passion fruit]. Rev Fac Agron (La Plata). 111:41-47.

Cavalcante IHL, Rocha LF, Silva Junior GB, Falcão Neto R, Silva RRS. 2011. Seedling production of gurguéia nut (Dypterix lacunifera Ducke) I: seed germination and suitable substrates for seedlings. Int J Plant Prod. 5:319-322.

Costa E, Santos LCR, Carvalho C, Leal PAM, Gomes VA. 2011. Volumes de substratos comerciais, solo e composto orgânico afetando a formação de mudas de maracujazeiro amarelo em diferentes ambientes de cultivo [Effect of varying volumes of commercial substrates, soil and organic compost on yellow passion fruit seedlings growth in different cultivation conditions]. Rev Ceres. 58:216-222.

FAO. 2014. Statistical database [Internet]. Rome: Food and Agriculture Organization; [cited 2015 Jan 20]. Available from: http://www.faostat.fao.org.

Galinha C, Bilsborough G, Tsiantis M. 2009. Hormonal input in plant meristems: a balancing act. Semin Cell Dev Biol. 20:1149-1156.

Hörn W. 1996. Zierpflanzenbau. Berlin: Blackwell.

Lopes JC, Bono GM, Alexandre RS, Maia VM. 2007. Germinação e vigor de plantas de maracujazeiro amarelo em diferentes estádios de maturação do fruto, arilo e substrato [Seed 
germination and vigor of yellow passion plants under different maturation stages of fruit, aril and substrate]. Ciênc Agrotec. 31:1340-1346.

Machado RAF. 1998. Fósforo e zinco na nutrição e crescimento de mudas de maracujazeiro-amarelo (Passiflora edulis f. flavicarpa Deg.) [Phosphorus and zinc on nutritional status and growth of yellow passion fruit seedlings (Passiflora edulis f. flavicarpa Deg.)] [Ph.D. thesis]. Lavras (MG): Federal University of Lavras.

Maguire JD. 1962. Speed of germination - aid in selection aid evolution for seedling emergence and vigor. Crop Sci. 2:176-177.

Malavolta E, Vitti GC, Oliveira SA. 1997. Avaliação do estado nutricional das plantas: princípios e aplicações [Evaluation of plant nutritional status: principles and practices]. Piracicaba: Potafos.

Marschner H. 2005. Mineral nutrition of higher plants. London: Academic Press.

Martín-Rejano EM, Camacho-Cristóbal JJ, Herrera-Rodríguez MB, Rexach J, Navarro-Gochicoa MT, González-Fontes A. 2011. Auxin and ethylene are involved in the responses of root system architecture to low boron supply in Arabidopsis seedlings. Physiol Plant. 142:170-178.

Mirshekari B. 2012. Seed priming with iron and boron enhances germination and yield of dill (Anethum graveolens). Turk J Agric For. 36:27-33.

Oliveira IVM, Cavalcante ÍHL, Martins ABG. 2006. Influência do substrato na emergência de plântulas de sapota preta [Influence of substrate on seedling emergence of black sapote]. Caatinga. 19:383-386.

Oyinlola EY. 2007. Effect of boron fertilizer on yield and oil content of three sunflower cultivars in the Nigerian Savanna. J Agron. 6:421-426.

Prado RM, Natale W, Rozane DE. 2006. Níveis críticos de boro no solo e na planta para o cultivo de mudas de maracujazeiro-amarelo [Boron application on nutritional status and dry matter production of passion fruit seedlings]. Rev Bras Frutic. 28:305-309.

Röber R, Schacht H. 2008. PflanzenernährungimGartenbau. Munich: Ulmer Press.

Sousa GB, Cavalcante LF, Cavalcante IHL, Beckman-Cavalcante MZ, Nascimento JAM. 2008. Salinidade do substrato contendo biofertilizante para a formação de mudas de maracujazeiro irrigado com água salina [Salinity of substrate containing biofertilizer to production of passion fruit seedlings irrigated with saline water]. Caatinga. 21:172-180.

Sousa GG, Novelino JO, Scalon SQP, Marchetti ME. 2011. Growth of passion fruit seedlings according to boron and termites mound nest material fertilizing. Pesqui Agropecu Trop. 41:170-178.

Wagner Jr A, Alexandre RS, Negreiro JR, Pimentel LD, Costa e Silva JO, Bruckner CH. 2006. Influência do substrato na germinação e desenvolvimento inicial de plantas de maracujazeiro amarelo (Passiflora edulis Sims f. flavicarpa Deg) [Effects of substrate on germination and initial growth of yellow passion fruit (Passiflora edulis Sims f. flavicarpa Deg)]. Ciênc Agrotec. 30:643-647.

Wang B-L, Shi L, Li Y-X, Zhang W-H. 2010. Boron toxicity is alleviated by hydrogen sulfide in cucumber (Cucumis sativus L.) seedlings. Planta. 231:1301-1309. 